\title{
Innovations in primary mental health care
}

\section{Authors:}

1st Author Name: Lennart Reifels

Qualifications: Dipl.-Psych. (Germany)

Position: Research Fellow

Institution or Affiliation: Centre for Health Policy, Programs and

Economics, Melbourne School of Population Health, University of

Melbourne

Address: 207 Bouverie Street, Carlton, 3010, Victoria, Australia

Email: I.reifels@unimelb.edu.au

2nd Author Name: Bridget Bassilios

Qualifications: DPsych

Position: Research Fellow

Institution or Affiliation: Centre for Health Policy, Programs and

Economics, Melbourne School of Population Health, University of

Melbourne

Address: 207 Bouverie Street, Carlton, 3010, Victoria, Australia

Email: b.bassilios@unimelb.edu.au

3rd Author Name: Kylie E. King

Qualifications: DPsych

Position: Research Fellow

Institution or Affiliation: Centre for Health Policy, Programs and

Economics, Melbourne School of Population Health, University of

Melbourne

Address: 207 Bouverie Street, Carlton, 3010, Victoria, Australia

Email: k.king@unimelb.edu.au

4th Author Name: Justine R. Fletcher

Qualifications: MPsych

Position: Research Fellow

Institution or Affiliation: Centre for Health Policy, Programs and

Economics, Melbourne School of Population Health, University of

Melbourne

Address: 207 Bouverie Street, Carlton, 3010, Victoria, Australia

Email: justine.fletcher@unimelb.edu.au

5th Author Name: Grant Blashki

Qualifications: MD

Position: Associate Professor

Institution or Affiliation: Nossal Institute for Global Health, University of

Melbourne

Address: 161 Barry Street, Carlton, 3010, Victoria, Australia

Email: gblashki@unimelb.edu.au

6th Author Name: Jane E. Pirkis 
Qualifications: PhD

Position: Professor

Institution or Affiliation: Centre for Health Policy, Programs and

Economics, Melbourne School of Population Health, University of

Melbourne

Address: 207 Bouverie Street, Carlton, 3010, Victoria, Australia

Email: j.pirkis@unimelb.edu.au 
1. What is known about the topic? It is recognised that innovative approaches are required to tailor mental health programs for hard-to-reach and at-risk population groups. Divisions of General Practice have implemented innovations in the Access to Allied Psychological Services (ATAPS) program for several years.

2. What does this paper add? Drawing on data from an ongoing national ATAPS evaluation, this paper presents a systematic analysis of the uptake, outcomes and issues associated with provision of the innovative ATAPS program.

3. What are the implications for practitioners? The findings highlight the benefits of introducing innovations in primary mental health care in terms of increased access to care and positive consumer outcomes. They also identify challenges to and facilitators of the implementation process which can inform innovation efforts in other primary care contexts.

Key words: Diffusion of innovation; primary care; mental health services 


\section{Abstract}

Objective: We review the evidence on innovations in Tier 2 of the Access to Allied Psychological Services (ATAPS) program which is designed to facilitate the provision of primary mental health care to hard-to-reach and at-risk population groups (including women with perinatal depression, people at risk of self-harm or suicide, people experiencing or at risk of homelessness, people affected by the 2009 Victorian bushfires, people in remote locations, Aboriginal and Torres Strait Islanders and children with mental disorders) and the trialling of new modalities of service delivery (e.g., telephone-based or web-based CBT). The primary focus is on the uptake, outcomes and issues associated with the provision of ATAPS Tier 2. Methods: Drawing on data from an ongoing national ATAPS evaluation, including a national minimum data set, key informant interviews and surveys, the impact of ATAPS innovations is analysed and illustrated through program examples. Results: ATAPS Tier 2 facilitates access to, uptake of and positive clinical outcomes from primary mental health care for population groups with particular needs, although it requires periods of time to implement locally. Conclusions: Relatively simple innovations in mental health program design can have important practical ramifications for service provision, extending program reach and improving mental health outcomes for target populations. 


\section{Introduction}

As a pillar of the Australian primary mental health care system, the Access to Allied Psychological Services (or ATAPS) program has been implemented through Divisions of General Practice (DGPs) since 2003. The ATAPS program is a key component of the Better Outcomes in Mental Health Care program which enables general practitioners to refer consumers to allied health professionals for a specified number of sessions (up to 12 in a calendar year and in exceptional circumstances 18) of evidence-based mental health care (typically cognitive behavioural therapy, or CBT). ${ }^{1}$ To be eligible for this care, consumers must have a diagnosis of a mental disorder and a mental health treatment plan developed by a general practitioner. Up to 12 group sessions per calendar year are also available.

The nature and direction of the ATAPS program have been shaped significantly over the years through various policy changes, including the introduction of the Better Access program in 2006 which facilitates access to mental health care via a number of Medicare Benefits Schedule items. In response to these policy changes, since 2008 Australian government funding has enabled DGPs to introduce innovative ATAPS subprograms which specifically target hard-to-reach and at-risk population groups (including women with perinatal depression (PND), people at risk of self-harm or suicide, people experiencing or at risk of homelessness, people affected by the 2009 Victorian bushfires, people in remote locations, Aboriginal and Torres Strait Islanders, children with mental disorders) and/or use new modalities of service delivery (e.g., telephone-based or web-based CBT). The original ATAPS program is now being referred to as Tier 1 or general ATAPS, and these so-called Tier 2 programs have aimed to tailor services towards the needs of target groups by introducing greater flexibilities in program access, eligibility and service provision (including through new interventions and delivery models). ${ }^{2}$ More recently the impetus for ATAPS innovation was underpinned by recommendations of a program review which highlighted four key areas for reform: better addressing service gaps; increasing efficiency; encouraging innovation; and improving quality. ${ }^{3}$ 
A common definition defines innovation as:

“... the intentional introduction and application within a role, group or organization of ideas, processes, products or procedures, new to the relevant unit of adoption, designed to significantly benefit the individual, the group, organization or wider society. ${ }^{\prime 4}$

While this definition captures three key characteristics of the innovation concept (i.e., novelty, application, and intended benefit), others have distinguished health care innovations relating to a product (e.g., goods, services, clinical procedures), a process (e.g., delivery method), or a structure (e.g., underpinning infrastructure or business model). ${ }^{5}$

Table 1 outlines innovation strategies adopted in the design and delivery of ATAPS Tier 2 in order to tailor the general ATAPS model to the circumstances of hard-to-reach and at-risk population groups.

Insert Table 1 about here

These innovation strategies primarily involved the introduction of: (1) new provisional referral pathways (in addition to GP referral); (2) target group specific interventions; (3) new delivery modalities (such as outreach, and telephone-based provision); (4) new flexible session modes (e.g., enabling various configurations of child/ren and or parent/s to be involved in sessions); (5) relaxation of the formal diagnosis requirement; and 6) relaxation of the limit on session numbers for people affected by bushfires and people at risk of self-harm or suicide. Naturally, the design and introduction of program innovations can also have ramifications for program implementation thereby impacting on structural aspects underpinning service delivery such as resourcing, staffing, service policies and partnerships. Program specific operational guidelines (7) and dedicated funding (8) were provided to DGPs to aid the establishment and ongoing operation of new ATAPS services. 
The majority of the innovation strategies were related to the 'process' dimension of innovation (1-7), with some strategies also related to the 'product' $(2-4)$ and 'structure' $(7,8)$ dimensions. The extent to which innovation strategies were genuinely novel to DGPs (as the units of adoption) varied largely dependent on the types of programs already provided.

As the primary health care landscape is changing rapidly and DGPs are increasingly called upon to respond to local community needs, we examined the uptake, outcomes and issues associated with the provision of innovative Tier 2 ATAPS. We did this using data from our broader evaluation of ATAPS, which has been described in detail elsewhere. ${ }^{6}$ 


\section{Methods}

We undertook a systematic analysis of data from our ongoing national evaluation of the ATAPS program in order to analyse the impact of innovations on ATAPS Tier 2 program uptake, outcomes and issues associated with service provision.

A purpose-designed national minimum dataset provided data on ATAPS Tier 2 consumer uptake and clinical outcomes for the period 1 April 2008 to 30 June 2011 (extracted on 4 July 2011). Repeated measures dependent t-tests for paired samples of pre- and post-treatment scores on a number of clinical outcome measures were conducted for programs with sufficient data, including the PND, Suicide and Bushfire programs. Programs with less than 50 matched pairs of outcome data on a given outcome measure were excluded from analysis, as were outcome measures with fewer than 50 observations, and consumers without a matched pair of pre- and post-treatment scores.

Qualitative data from interviews and surveys with 71 DGP project officers and managers involved in selected programs for which data were available including the $\mathrm{T}-\mathrm{CBT}(\mathrm{N}=22)$, Suicide $(\mathrm{N}=38)$ and Bushfire $(\mathrm{N}=11)$ programs were analysed thematically in order to examine issues associated with service provision. ${ }^{7}$ 


\section{Results}

\section{Program Uptake}

Table 2 outlines the uptake of Tier 2 ATAPS in terms of the number of referrals and sessions of care delivered to consumers of the various target groups. Overall, the data indicate that between April 2008 and June 2011, a total of 9,613 referrals resulted in 41,025 sessions of care being delivered via Tier 2 ATAPS programs, with the number of sessions per program ranging from 324 for the T-CBT program to 12,569 for the Suicide program. The average number of sessions per referral varied slightly between 3.9 for Rural and Remote to 6.5 for the Bushfire program.

Insert Table 2 about here

\section{Program Outcomes}

Paired t-tests of mean differences in pre- and post-treatment scores were conducted for six outcome measures including the Depression, Anxiety, Stress Scales (DASS), ${ }^{8}$ the Edinburgh Post Natal Depression Scale (EPNDS), ${ }^{9}$ the Kessler 10 (K10), ${ }^{10}$ and the Modified Scale for Suicidal Ideation (MSSI). ${ }^{11}$ For all of these measures a positive difference between pre- and post-treatment scores is indicative of improvement. Table 3 demonstrates that Tier 2 ATAPS programs including PND, Suicide and Bushfire produced statistically significant outcomes that were indicative of clinical improvement.

Insert Table 3 about here

\section{Service Provision}

Table 4 summarises key themes identified by DGP project officers and managers in relation to the provision of innovative Tier 2 ATAPS programs. 
Key implementation challenges encountered by DGPs included: delays in commencement often due to the need to establish necessary operating policies and infrastructure; engagement and training of providers; and broader issues of service coordination. Key implementation facilitators involved: flexible ATAPS guidelines; the availability of funding; the ability to build on the pre-existing ATAPS platform (including a skilled provider base, familiar processes, good relationships with referrers); persistence in service promotion; and effective organisational frameworks for provider support, program targeting and coordination. The data from 19 interviews conducted with DGP project officers towards the completion of the Suicide pilot program indicated that most DGPs had found ways to successfully overcome initial 'teething issues' of implementation as the program matured over time. Nevertheless, DGPs also continued to report some ongoing issues in relation to GP engagement and variable allied health provider satisfaction with the quality of suicide prevention training, perceived by some providers as a barrier to their involvement in the program. 


\section{Discussion}

Australia's primary health care reform and the move to Medicare Locals mean that there is an onus on DGPs to develop mental health services which are not only effective but targeted and responsive to the needs of local communities. ${ }^{12}$ While the general ATAPS (Tier 1) program has always been flexibly operationalised by DGPs vis-à-vis local circumstances, ${ }^{13}$ Tier 2 ATAPS program innovations have introduced deliberate modifications in program parameters aimed at tailoring primary mental health care services to the circumstances of hard-to-reach and at risk population groups.

The available data indicate that Tier 2 programs produced promising results in terms of consumer uptake and clinical outcomes. As of June 2011, Tier 2 ATAPS programs accounted for $4 \%$ of all ATAPS referrals and sessions of care delivered nationally (with the rest attributable to Tier 1 ATAPS introduced in 2003). ${ }^{14}$ Tier 2 programs enabled delivery of a significant number of sessions of care to target groups, with differences in uptake largely corresponding to relative program infancy. While there is some evidence of a preference for face-to-face service delivery, the telephone modality now provides a complementary avenue for service access across all ATAPS programs. Importantly, Tier 2 programs produced positive clinical consumer outcomes commensurate with Tier 1 ATAPS. ${ }^{14}$

The Tier 2 implementation has yielded important insights regarding challenges and facilitators of the innovation process which may be of relevance to other primary health care contexts. The implementation experience specifically highlighted the critical dependence of largely process- and product-driven innovations on the existence or establishment of effective service structures. Dissemination of innovations ${ }^{15}$ through existing service structures provided DGPs with the ability to draw on their infrastructure, staff resources, and experience in delivering similar services. However, to varying degrees DGPs also faced significant implementation challenges due to the need to establish effective mechanisms for service operation, promotion, coordination, referrer engagement and provider support. In addition, innovation implementation often absorbed considerable resources on the part of DGPs. 
The findings highlight the potential benefits of providing greater structural support and guidance to DGPs during the implementation stage. This may be provided through program guidelines outlining the importance of developing effective organisational frameworks for clinical governance, service coordination, promotion and external partnerships. At the time of writing, all of ATAPS Tier 2 referred to in this paper, is now being widely implemented across Australia by Medicare Locals.

The study was limited by a lack of available data on sub-components of Tier 2 other than those reported; the relatively small proportion of matching pre- and post-treatment outcome data; and a lack of data on the perspectives of consumers and other stakeholders. This is due to the infancy of some of the Tier 2 subcomponents.

\section{Conclusions}

Innovative Tier 2 ATAPS programs show promise as a primary mental health care strategy to target hard-toreach and at risk population groups through means that are not available via Tier 1 ATAPS or the Better Access program. Building on the solid Tier 1 ATAPS foundation, relatively simple innovations in mental health program design can have important practical ramifications for service provision, extending program reach and improving mental health outcomes of target populations.

\section{Conflicts of interests}

The authors declare that no conflicts of interest exist. 


\section{References}

1. Hickie I, Groom G. Primary care-led mental health service reform: An outline of the Better Outcomes in Mental Health Care initiative. Australas Psychiatry. 2002;10:376-82.

2. Australian Government Department of Health and Ageing. 2010-2011 Operational Guidelines for the Access to Allied Psychological Services Component of the Better Outcomes in Mental Health Care Program. Canberra: Australian Government Department of Health and Ageing, 2010.

3. Australian Government Department of Health and Ageing. Outcomes and proposed next steps: Review of the Access to Allied Psychological Services Component of the Better Outcomes in Mental Health Care Program. Canberra: Australian Government Department of Health and Ageing, 2010.

4. West MA, Farr JL, editors. Innovation and creativity at work: Psychological and organizational strategies. Chichester, UK: Wiley; 1990.

5. Varkey P, Horne A, Bennet KE. Innovation in health care: A primer. Am J Med Qual. 2008;23:3828.

6. Kohn F, Pirkis J, Morley B, Naccarella L, Blashki G. Utilisation of findings from the evaluation of a major primary mental health care initiative in Australia. Eval J Australas. 2007;7(2):12-24.

7. Flick U. Coding and categorizing. An introduction to qualitative research. London: Sage; 2006. p. 295-318.

8. Lovibond SH, Lovibond PF. Manual for the Depression Anxiety Stress Scales, 2nd Edition. Sydney: Psychology Foundation; 1995.

9. Cox JL, Holden JM, Sagovsky R. Detection of postnatal depression: Development of the 10-item Edinburgh Postnatal Depression Scale. Br J Psychiatry. 1987(150):782-6.

10. Kessler RC, Andrews G, Colpe LJ, Hiripi E, Mroczek DK, Normand SLT, Walters EE, Zaslavsky AM. Short screening scales to monitor population prevalences and trends in non-specific psychological distress. Psychol Med. 2002;32(6):959-76.

11. Miller IW, Norman WH, Dow MG, Bishop SB. The Modified Scale for Suicidal Ideation: Reliability and validity. J Consult Clin Psychol. 1986;54(5):724-5.

12. Australian Government Department of Health and Ageing. Medicare Locals: Discussion paper on governance and functions. Canberra: Australian Government Department of Health and Ageing, 2010.

13. Pirkis J, Burgess P, Kohn F, Morley B, Blashki G, Naccarella L. Models of psychological service provision under Australia's Better Outcomes in Mental Health Care program. Aust Health Rev. 2006;30(3):277-85.

14. Bassilios B, King K, Fletcher J, Reifels L, Blashki G, Burgess P, Pirkis J. Evaluating the Access to Allied Psychological Services component of the Better Outcomes in Mental Health Care Program: Eighteenth Interim Evaluation Report: An overview of the achievements of Tier 1 and Tier 2 ATAPS. Melbourne: Centre for Health Policy, Programs and Economics, Melbourne School of Population Health, The University of Melbourne, 2011.

15. Greenhalgh T, Robert G, Macfarlane F, Bate P, Kyriakidou O. Diffusion of innovations in service organizations: Systematic review and recommendations. Milbank Q. 2004;82(4):581-629. 


\section{Table 1: Overview of ATAPS Tier 2 program innovations}

\begin{tabular}{|c|c|}
\hline ATAPS Tier 2 program & Key program innovations \\
\hline $\begin{array}{l}\text { Perinatal Depression (PND) } \\
\text { Introduced April } 2008\end{array}$ & $\begin{array}{l}\text { - Provisional referral option (midwives, obstetricians, } \\
\text { maternal and child health nurses) } \\
\text { - New intervention (family therapy) }\end{array}$ \\
\hline $\begin{array}{l}\text { Telephone-CBT Pilot (T-CBT) } \\
\text { July } 2008 \text { - June } 2010\end{array}$ & $\begin{array}{l}\text { - New telephone modality (telephone-, web- and video } \\
\text { conferencing-based modalities now available across } \\
\text { all ATAPS programs) }\end{array}$ \\
\hline $\begin{array}{l}\text { Specialist Suicide Services (Suicide) } \\
\text { Piloted October } 2008 \text { - June 2011; } \\
\text { now expanded to all DGPs }\end{array}$ & $\begin{array}{l}\text { - } \quad \text { Provisional referral option (community mental health } \\
\text { - } \quad \text { No diagnosis requirement } \\
\text { - } \quad \text { No limit on session numbers } \\
\text { - } \quad \text { Shorter more intensive support model }\end{array}$ \\
\hline $\begin{array}{l}\text { Victorian Bushfires } 2009 \text { (Bushfire) } \\
\text { Introduced February } 2009\end{array}$ & $\begin{array}{l}\text { - } \quad \text { Provisional referral option (bushfire case managers) } \\
\text { - } \quad \text { Originally no diagnosis requirement } \\
\text { - } \quad \text { No limit on session numbers }\end{array}$ \\
\hline $\begin{array}{l}\text { Aboriginal and Torres Strait Islander (ATSI) } \\
\text { Introduced July } 2010\end{array}$ & 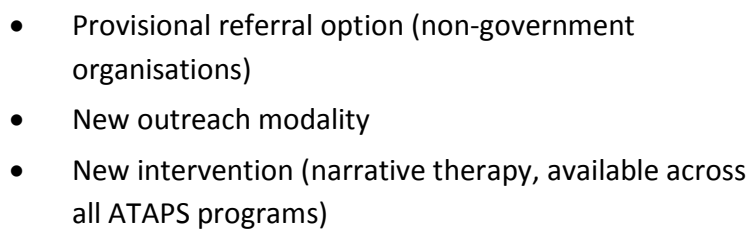 \\
\hline $\begin{array}{l}\text { Children with Mental Disorders (Child) } \\
\text { Introduced July } 2010\end{array}$ & $\begin{array}{l}\text { - New interventions (family therapy, parent training in } \\
\text { behaviour management, play therapy) } \\
\text { Flexible session mode: child alone, parent(s) alone, } \\
\text { child and parents, child in group, parent(s) in group, } \\
\text { child(ren) and parent(s) in group }\end{array}$ \\
\hline $\begin{array}{l}\text { People experiencing or at risk of } \\
\text { homelessness (Homelessness) } \\
\text { Introduced July } 2010\end{array}$ & $\begin{array}{l}\text { Provisional referral option (non-government } \\
\text { organisations) } \\
\text { - } \quad \text { New outreach modality (including mobile clinics) }\end{array}$ \\
\hline $\begin{array}{l}\text { Rural and Remote } \\
\text { Introduced July } 2010\end{array}$ & - $\quad$ New outreach modality \\
\hline
\end{tabular}

NB. Because of their relative infancy, more recently introduced Tier 2 programs were not included. 
Table 2: Referrals and sessions by ATAPS Tier 2 program, April 2008 - June 2011

\begin{tabular}{|c|c|c|c|c|c|}
\hline ATAPS Tier 2 program & $\begin{array}{c}\text { No. } \\
\text { DGPs }\end{array}$ & $\begin{array}{c}\text { No. } \\
\text { referrals }\end{array}$ & $\begin{array}{c}\text { No. referrals } \\
\text { resulting in } \\
\text { sessions }\end{array}$ & $\begin{array}{c}\text { No. } \\
\text { sessions }\end{array}$ & $\begin{array}{c}\text { Average no. } \\
\text { sessions per } \\
\text { referral }^{\mathrm{a}}\end{array}$ \\
\hline ATSI & 20 & 209 & $173(83 \%)$ & 831 & 4.8 \\
\hline Bushfire & 9 & 1,891 & $1,535(81 \%)$ & 9,949 & 6.5 \\
\hline Child & 49 & 852 & $618(73 \%)$ & 2,825 & 4.6 \\
\hline Homelessness & 26 & 554 & $454(82 \%)$ & 1,713 & 3.7 \\
\hline PND & 98 & 2,886 & 2,291 (79\%) & 11,667 & 5.1 \\
\hline Rural and Remote & 13 & 495 & $292(59 \%)$ & 1,147 & 3.9 \\
\hline Suicide & 41 & 2,654 & $2,310(87 \%)$ & 12,569 & 5.4 \\
\hline $\mathrm{T}-\mathrm{CBT}$ & 7 & 72 & $58(81 \%)$ & 324 & 5.6 \\
\hline ATAPS Tier 2 total & $106^{b}$ & 9,613 & $7,731(80 \%)$ & 41,025 & 5.3 \\
\hline
\end{tabular}

${ }^{\mathrm{a}}$ Excluding referrals for which there were no sessions. ${ }^{\mathrm{b}}$ Including DGPs providing multiple ATAPS Tier 2 programs. 
Table 3: Pre- and post-treatment outcome scores for consumers by ATAPS Tier 2 program

\begin{tabular}{|c|c|c|c|c|c|c|c|c|c|c|c|c|c|c|c|}
\hline \multirow[b]{2}{*}{$\begin{array}{c}\text { Meas } \\
\text { ure }\end{array}$} & \multicolumn{5}{|c|}{ PND } & \multicolumn{5}{|c|}{ Suicide } & \multicolumn{5}{|c|}{ Bushfire } \\
\hline & $\mathrm{n}$ & $\begin{array}{c}\text { Pre- } \\
\text { treatm } \\
\text { ent } \\
\text { mean } \\
\text { (S.D.) }\end{array}$ & $\begin{array}{l}\text { Post- } \\
\text { treatm } \\
\text { ent } \\
\text { mean } \\
\text { (S.D.) }\end{array}$ & $\begin{array}{l}\text { Mean } \\
\text { differe } \\
\text { nce } \\
\text { (S.D.) }\end{array}$ & $95 \% \mathrm{Cl}$ & $n$ & $\begin{array}{c}\text { Pre- } \\
\text { treatm } \\
\text { ent } \\
\text { mean } \\
\text { (S.D.) }\end{array}$ & $\begin{array}{l}\text { Post- } \\
\text { treat } \\
\text { ment } \\
\text { mean } \\
\text { (S.D.) }\end{array}$ & $\begin{array}{l}\text { Mean } \\
\text { differe } \\
\text { nce } \\
\text { (S.D.) }\end{array}$ & $95 \% \mathrm{Cl}$ & $\mathrm{n}$ & $\begin{array}{c}\text { Pre- } \\
\text { treatm } \\
\text { ent } \\
\text { mean } \\
\text { (S.D.) }\end{array}$ & $\begin{array}{l}\text { Post- } \\
\text { treatm } \\
\text { ent } \\
\text { mean } \\
\text { (S.D.) }\end{array}$ & $\begin{array}{c}\text { Mean } \\
\text { differe } \\
\text { nce } \\
\text { (S.D.) }\end{array}$ & $95 \% \mathrm{Cl}$ \\
\hline $\begin{array}{l}\text { DASS- } \\
\text { A }\end{array}$ & $\begin{array}{c}13 \\
0\end{array}$ & $\begin{array}{l}11.8 \\
(9.4)\end{array}$ & $\begin{array}{c}6.3 \\
(7.4)\end{array}$ & $\begin{array}{l}5.5^{*} \\
(8.5)\end{array}$ & $\begin{array}{l}{[4.07} \\
7.01]\end{array}$ & $\begin{array}{c}12 \\
4\end{array}$ & $\begin{array}{c}17.8 \\
(10.2)\end{array}$ & $\begin{array}{l}10.0 \\
(8.1)\end{array}$ & $\begin{array}{c}7.8^{*} \\
(9.8)\end{array}$ & $\begin{array}{l}\text { [6.07, } \\
9.54]\end{array}$ & - & - & - & - & - \\
\hline $\begin{array}{l}\text { DASS- } \\
\text { D }\end{array}$ & $\begin{array}{c}13 \\
1\end{array}$ & $\begin{array}{c}17.1 \\
(10.0)\end{array}$ & $\begin{array}{c}8.7 \\
(8.1)\end{array}$ & $\begin{array}{l}8.4^{*} \\
(10.7)\end{array}$ & $\begin{array}{l}{[6.52,} \\
10.21]\end{array}$ & $\begin{array}{c}12 \\
4\end{array}$ & $\begin{array}{c}25.9 \\
(10.8)\end{array}$ & $\begin{array}{l}12.2 \\
(9.1)\end{array}$ & $\begin{array}{l}13.7^{*} \\
(12.4)\end{array}$ & $\begin{array}{c}{[11.52,} \\
15.93]\end{array}$ & - & - & - & - & - \\
\hline $\begin{array}{l}\text { DASS- } \\
\mathrm{S}\end{array}$ & $\begin{array}{c}13 \\
1\end{array}$ & $\begin{array}{l}20.8 \\
(9.2)\end{array}$ & $\begin{array}{l}13.5 \\
(9.0)\end{array}$ & $\begin{array}{l}7.4^{*} \\
(9.0)\end{array}$ & $\begin{array}{l}{[5.81,} \\
8.93]\end{array}$ & $\begin{array}{c}12 \\
1\end{array}$ & $\begin{array}{c}23.4 \\
(10.9)\end{array}$ & $\begin{array}{l}13.5 \\
(9.2)\end{array}$ & $\begin{array}{c}9.9 * \\
(11.3)\end{array}$ & $\begin{array}{l}{[7.83,} \\
11.90]\end{array}$ & - & - & - & - & - \\
\hline $\begin{array}{l}\text { EPND } \\
\mathrm{S}\end{array}$ & $\begin{array}{c}17 \\
3\end{array}$ & $\begin{array}{l}16.4 \\
(5.3)\end{array}$ & $\begin{array}{c}9.6 \\
(6.3)\end{array}$ & $\begin{array}{c}6.8^{*} \\
(7.4)\end{array}$ & $\begin{array}{l}{[5.66} \\
7.86]\end{array}$ & - & - & - & - & - & - & - & - & - & - \\
\hline K-10 & 99 & $\begin{array}{l}30.7 \\
(7.5)\end{array}$ & $\begin{array}{l}20.3 \\
(8.0)\end{array}$ & $\begin{array}{r}10.4^{*} \\
(9.1)\end{array}$ & $\begin{array}{l}{[8.56,} \\
12.21]\end{array}$ & $\begin{array}{c}13 \\
8\end{array}$ & $\begin{array}{l}34.5 \\
(7.7)\end{array}$ & $\begin{array}{l}24.3 \\
(9.4)\end{array}$ & $\begin{array}{l}10.2^{*} \\
(9.9)\end{array}$ & $\begin{array}{l}{[8.53,} \\
11.88]\end{array}$ & 88 & $\begin{array}{l}31.0 \\
(7.5)\end{array}$ & $\begin{array}{l}25.2 \\
(7.5)\end{array}$ & $\begin{array}{c}5.8^{*} \\
(7.2)\end{array}$ & $\begin{array}{c}{[4.30,} \\
7.34]\end{array}$ \\
\hline MSSI & - & - & - & - & - & $\begin{array}{c}24 \\
1\end{array}$ & $\begin{array}{c}11.0 \\
(11.1)\end{array}$ & $\begin{array}{c}2.5 \\
(5.3)\end{array}$ & $\begin{array}{r}8.5^{*} \\
(10.1)\end{array}$ & $\begin{array}{l}{[7.25} \\
9.81]\end{array}$ & - & - & - & - & - \\
\hline
\end{tabular}

NB. ${ }^{*} p<0.001$; values may not sum due to rounding 
Table 4: Key themes in the provision of ATAPS Tier 2 programs

\begin{tabular}{|c|c|c|c|}
\hline Key themes & T-CBT & Suicide & Bushfire \\
\hline $\begin{array}{l}\text { Implementation } \\
\text { challenges }\end{array}$ & $\begin{array}{l}\text { - } \quad \text { Delay in commencement } \\
\text { Delay in availability of } \\
\text { mandatory AHP training } \\
\text { Lack of registered / } \\
\text { trained providers } \\
\text { - Slow GP uptake and low } \\
\text { referral rate } \\
\text { - } \quad \text { Service promotion and } \\
\text { engagement in a pilot } \\
\text { Preference for face-to- } \\
\text { face service delivery } \\
\text { Assessment of consumer } \\
\text { risk and liability concerns } \\
\text { Additional paperwork and } \\
\text { data collection } \\
\text { Telephone equipment / } \\
\text { coverage / call costs } \\
\text { Lack of travel funding to } \\
\text { conduct initial face-to-face } \\
\text { assessment }\end{array}$ & $\begin{array}{l}\text { - } \quad \text { Delay in commencement } \\
\text { Developing operating } \\
\text { policies (for client risk } \\
\text { assessment, service } \\
\text { eligibility and referral) } \\
\text { - } \text { Establishing partnerships } \\
\text { (with ED and state mental } \\
\text { health services) } \\
\text { Delayed availability of } \\
\text { - } \quad \text { Limandatory AHP training } \\
\text { - } \quad \text { and adequacy } \\
\text { (i.e., shortages; workload; } \\
\text { lack of program familiarity) } \\
\text { Inappropriate referrals from } \\
\text { GPs and mental health } \\
\text { - } \quad \text { Nervices } \\
\text { - } \quad \text { service promotion for persistence in } \\
\text { inited access for } \\
\text { indigenous and chronically } \\
\text { suicidal consumers } \\
\text { Administrative requirements } \\
\text { Insufficient level or stop- } \\
\text { start nature of funding } \\
\text { Pilot program engagement }\end{array}$ & 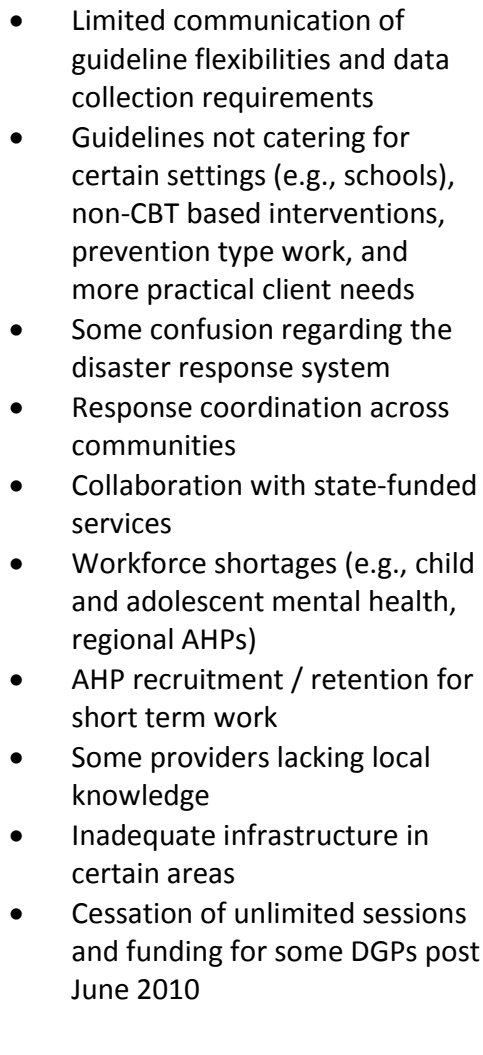 \\
\hline $\begin{array}{l}\text { Implementation } \\
\text { facilitators }\end{array}$ & $\begin{array}{ll}\text { - } & \text { Positive AHP response and } \\
\text { - } & \text { Gilled AHP team } \\
& \text { Good GP / AHP } \\
\text { relationship } \\
\text { - } \quad \text { Flexible guidelines (incl. } \\
\text { multimodal delivery) } \\
\text { - } \text { Good organisational } \\
\text { processes and service } \\
\text { targeting } \\
\text { - } \\
\text { - } \\
\text { Uraining availability } \\
\text { - } \quad \text { strategies multiple promotion } \\
\text { - } \quad \text { Eeduced paper work } \\
\text { - } \quad \text { Effective existing } \\
\text { telephone networks }\end{array}$ & 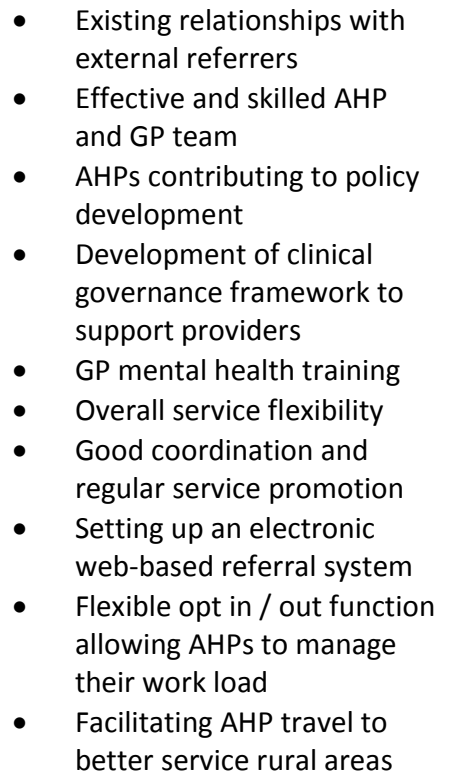 & 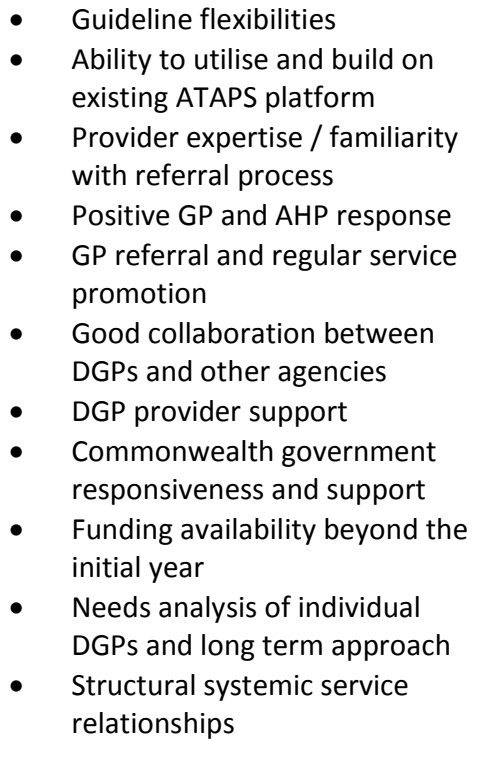 \\
\hline
\end{tabular}

NB. 'AHP' denotes allied health provider 


\section{University Library}

\section{- M M N E R VA A gateway to Melbourne's research publications}

Minerva Access is the Institutional Repository of The University of Melbourne

Author/s:

Reifels, L;Bassilios, B;King, KE;Fletcher, JR;Blashki, G;Pirkis, JE

Title:

Innovations in primary mental healthcare

Date:

2013-01-01

Citation:

Reifels, L., Bassilios, B., King, K. E., Fletcher, J. R., Blashki, G. \& Pirkis, J. E. (2013).

Innovations in primary mental healthcare. AUSTRALIAN HEALTH REVIEW, 37 (3),

pp.312-317. https://doi.org/10.1071/AH12203.

Persistent Link:

http://hdl.handle.net/11343/58422 